\title{
FAKTOR-FAKTOR YANG MEMENGARUHI MINAT SISWA SMP MASUK SMK DI KOTA PONTIANAK
}

\author{
Winna Dharmayanti \\ IKIP PGRI Pontianak \\ dharmayantiwinna@gmail.com \\ Sudji Munadi \\ Univeritas Negeri Yogyakarta \\ sudji.munadi@yahoo.co.id
}

\begin{abstract}
Abstrak
Penelitian ini bertujuan untuk mengetahui ; (1) minat siswa SMP masuk SMK di Kota Pontianak; (2) pengaruh pemahaman diri terhadap minat siswa SMP masuk SMK di Kota Pontianak; (3) pengaruh lingkungan terhadap minat siswa SMP masuk SMK di Kota Pontianak; (4) pengaruh citra SMK terhadap minat siswa SMP masuk SMK di Kota Pontianak; dan(5) pengaruh pemahaman diri, lingkungan dan citra SMK yang memengaruhi terhadap minat siswa SMP masuk SMK di Kota Pontianak secara bersama-sama. Jenis Penelitian ini adalah ex-post facto.Populasi Penelitian ini adalah seluruh siswa kelas IX SMP di Kota Pontianak yang berjumlah 8000 orang. Penentuan ukuran sampel menggunakan table Issac\& Michael. Daritable yang disediakan dengan taraf kesalahan5\%,diperoleh sampel sebesar350 orang. Pengambilan sampel dengan teknik clauster random sampling,pengumpulan datamenggunakan angket. Teknik analisa data dalam penelitian ini adalah statistik deskriptifyang digunakan untuk mendeskripsikan data masing - masing variabel dan analisis regresi yang digunakan untuk pengujian hipotesis. Hasil penelitian ini menunjukan bahwa (1) minat siswa SMP masuk SMK terdapat kategori baik dengan rata-rata skor 41,79; (2) terdapat pengaruh yang positif dan signifikan antara pemahaman diri terhadap minat siswa SMP masuk SMK di Kota Pontianak dengan nilai $r=0,743$; $p=0,000$; (3) terdapat pengaruh yang positif dan signifikan antara lingkungan terhadap minat siswa SMP masuk SMK di Kota Pontianak dengan nilai $r=0,527 ; p=0,000 ;$ (4) terdapat pengaruh yang positif dan signifikan antara citra SMK terhadap minat siswa masuk SMK dengan nilai $r=0,678 ; p=0,000$; dan (5) terdapat pengaruh yang positif dan signifikan antara pemahaman diri, lingkungan, dan citra SMK secara bersama-sama terhadap minat siswa SMP masuk SMK di Kota Pontianak. Prediksi perubahan Y ditunjukan oleh persamaan garis regresi $Y=-8,735+0,749 X_{1}+0,126 X_{2}+0,453 X_{3}$.
\end{abstract}

Kata kunci: Minat siswa, pemahaman diri, lingkungan, dan citra SMK.

\section{FACTORS AFFECTING JUNIOR HIGH SCHOOL STUDENTS' INTEREST IN STUDYING AT VOCATIONAL HIGH SCHOOL IN PONTIANAK CITY}

\begin{abstract}
This study aims to investigate: (1) junior high school (JHS) students'interest in studying at vocational high schools (VHSS) in Pontianak City, (2) the effect of self-understanding on JHS students' interest in studying at VHSs in Pontianak City, (3) the effect of the environment on JHS students' interest in studying at VHSS in Pontianak City, (4) the effect of the VHS image on JHS students' interest in studying at VHSs in Pontianak City, (5) the effects of the self-understanding, environment, and VHS image as an aggregate on JHS students' interest in studying at VHSS in Pontianak City. This was an ex post facto study. The research population comprised all Grade IX students of JHSs in Pontianak City with a total of 8000 students. The sample size was determined by the Isaac \& Michael table. According to the table with an error of 5\%, the sample consisted of 350 students. The sample was selected by means of the cluster random sampling technique and the data were collected through
\end{abstract}


a questionnaire. The data in the study were analyzed using descriptive statistics to describe the data of each variable and regression analysis to test the hypotheses. The results of the study are as follows. (1) JHS students' interest in studying at VHSS is good with a mean score of 41.79; (2) There is a significant positive effect of self-understanding on JHS students' interest in studying at VHSs in Pontianak City, with $r=0.743$ at $p=0.000$.;(3) There is a significant positive effect of the environment on JHS students' interest in studying at VHSs in Pontianak City, withr $=0.527$ at $p=$ $0.000 . ;$ (4) There is a significant positive effect of the VHS image on JHS students'interest in studying at VHSs in Pontianak City, with $r=0.678$ at $p=0.000$; (5) There are significant positive effects of the self-understanding, environment, and VHS image as an aggregate on JHS students' interest in studying at VHSs in Pontianak City. The prediction of the change in $Y$ is shown by the regression value equation $Y=-8.735+0.749 X_{1}+0.126 X_{2}+0.453 X_{3}$.

Keywords: students' interest, self-understanding, environment, VHS image

\section{PENDAHULUAN}

Sebagai lembaga pendidikan formal, sekolah sangat berperan untuk mewujudkan aspirasi-aspirasi nasional dan tujuan-tujuan pendidikan yang telah dirumuskan secara akurat. Mengingat pendidikan selalu bekenaan dengan pembinaan dan pengembangan manusia, maka keberhasilan pendidikan sangat bergantung pada individu. Salah satu individu yang dimaksud adalah siswa. Setiap siswa dituntut untuk belajar semaksimal mungkin sesuai dengan kemampuan, minat, dan bakat yang dimiliki dalam usaha mencapai tujuan yang diinginkan.

Sebagai siswa yang sedang mengikuti proses pendidikan dan pengajaran di jenjang sekolah menengah pertama (SMP) sudah sewajarnya bila siswa tersebut memiliki berbagai macam keinginan dan cita-cita setelah lulus. Mereka dihadapkan pada berbagai alternatif pilihan yang perlu dilakukan untuk mengantisipasi program yang harus ditempuh selanjutnya setelah menyelesaikan pendidikan. Dalam kondisi yang demikian ini kualitas kesiapan mental dan kemampuan siswa sangat berperan dalam proses pengambilan keputusan, artinya pihak luar hanya sebatas memberikan bimbingan dan pengarahan, sedangkan pengambilan keputusan sepenuhnya berada pada siswa itu sendiri setelah memperhatikan dan mempertimbangkan masukan dari pihak lain.

Para siswa dihadapkan berbagai macam pilihan untuk melanjutkan sekolah setalah mereka lulus, pilihan-pilihan tersebut antara lain melanjutkan ke jenjang yang lebih tinggi (SMA, SMK, atau MA), melanjutkan sekolah sambil mengikuti kursus baik akademik maupun keterampilan, tidak melanjutkan tetapi mengikuti khursus-khursus keterampilan, atau mencari pekerjaan yang memang diperuntukkan bagi lulusan SMP dan berbagai pilihan lainnya. Menentukan dan memilih salah satu program lanjutan sekolah lulusan SMP pada dasarnya adalah memilih suatu jalan atau media untuk mendapatkan suatu keahlian tertentu yang nantinya digunakan untuk mendapatkan pekerjaan tertentu. Dalam pemilihan sekolah lanjutan ini diharapkan siswa benar-benar memahami apa yang diinginkan, sehingga tidak adanya perasaan menyesal dikemudian hari atau bahkan putus sekolah.

Sekolah Menengah Kejuruan (SMK) merupakan lembaga pendidikan yang berorientasi pada pembentukan kecakapan hidup, yaitu melatih peserta didik untuk menguasai keterampilan yang dibutuhkan oleh dunia kerja terutama bisnis dan industri, memberikan pendidikan tentang wirausahaan, serta membentuk kecakapn hidup. Menjadikan SMK sebagai pilihan utama juga harus didukung oleh pengelola pendidikan dengan menyediakan sarana dan prasarana sekolah yang up to date. Karena perkembangan ilmu pengetahuan dan teknologi yang begitu cepat, sedangkan sarana dan prasarana sekolah yang minim masih menjadi penyebab utama terjadinya kurang sinkron dengan sarana yang dimiliki oleh industri. Akibatnya ketika mereka berada di industri yang sesungguhnya harus belajar dari awal kembali. Oleh karena itu pengelola SMK harus meningkatkan sarana dan prasarana praktek maupun sarana pendukung pembelajaran lainnya agar benar-benar bisa dihasilkan siswa lulusan yang kompeten dan sesuai dengan tuntutan dunia usaha / industri . 
Tingkat mutu suatu SMK tidak hanya dilihat dari tingkat lulusan siswa yang tinggi dalam ujian nasional maupun ujian akhir sekolah, tetapi yang sangat penting adalah Suatu SMK mampu menyelengarakan proses pendidikan yang bermutu dan menghasilkan lulusan yang siap bekerja serta diserap dengan baik oleh dunia industri. Program pembangunan citra positif SMK adalah untuk meningkatkan image positif di mata masyarakat umum, orang tua dan perusahaan penerimaan lulusan SMK. Meningkatkan rasa kebanggaan memasuki SMK bagi lulusan SMP, serta menciptakan rasa percaya diri bagi lulusan SMK untuk memasuki dunia usaha/dunia industri maupun menjadi perwirausaha mandiri.

Kualitas SMK yang bermutu dapat meningkatkan citra SMK dimata masyarakat dan sebaliknya citra SMK yang mutunya kurang baik dapat menimbulkan citra SMK yang kurang baik. Citra SMK yang baik dapat menjadi daya tarik minat masyarakat atau lulusan SMP untuk melanjutkan ke SMK. Maka dari itu para lulusan SMK mempunyai peran penting dalam pembentukan citra SMK dan berperan penting pula dalam menarik minat SMP untuk melanjutkan ke SMK.

Siswa SMK diharuskan untuk melakukan praktik menguasi setiap teknik keahlian sehingga mereka berpengalaman dan siap untuk berada langsung memasuki dunia kerja. Sehingga bagi Siswa SMP yang tidak memiliki kemampuan ekonomi yang kuat SMK adalah pilihan terbaik untuk melajutkan pendidikan. Namun tidak menutup kemungkinan juga para lulusan SMK dapat melajutkan pendidikan yang lebih tinggi lagi. Saat ini banyak SMK yang bertaraf internasional untuk menghadap persaingan era globalisasi. Citra SMK diharapkan mampu mengubah pola pandang masyarakat terhadap SMK. Pola pandang atau kesan masyarakat terhadap SMK pada masa lalu antara lain SMK sebagai lembaga pendidikan kelas dua, SMK hanya menghasilkan calon tenaga kerja kasar, hingga siswa SMK sering terlibat tawuran. Citra SMK yang positif dapat mendorong masyarakat menerima dengan baik para lulusan SMK

Sejauh ini masih kurangnya pihak sekolah SMK yang melakukan sosialiasi langsung ke
SMP seperti mengadakan seminar tentang apa itu SMK dan jurusan apa saja yang ada didalam SMK tersebut, atau bahkan melakukan serangkaian kegiatan misalnya perakitan untuk jurusan otomotif, membuat media pembelajaran bagi jurusan komputer dan lain-lain, sesuai dengan bidang keahlian yang dapat diikuti langsung oleh siswa SMP, sehingga siswa SMP mempunyai pengalaman yang menyenangkan dengan hal-hal yang berhubungan dengan SMK, dan meginginkan untuk terlibat langsung di dalam SMK itu sendiri.

Saat ini Pemerintah hanya gencar mempromosikan SMK di media cetak maupun elektronik nasional dengan harapan masyarakat lebih tertarik untuk menyekolahkan anaknya di SMK dari pada di SMA. Untuk meningkatkan kualitas SMK antara lain dengan melalui iklan televisi, media masa, radio dengan selogan SMK Bisa. Sosialisasi yang telah dilakukan pemerintah melalui media masa sudah cukup untuk memperbaiki citra SMK walaupun masih belum sampai menyentuh pada sasaran SMK yang sebenarnya. Iklan dengan bintang ternama yang ditayangkan di media televisi masih terasa kurang menyentuh karena siswa SMP atau orang tuanya tidak memahami dengan SMK yang mana, program apa dan sebagainya. Banyak faktor yang mempengaruhi terjadinya minat siswa untuk memilih sekolah ke SMK antara lain adalah pemahaman diri, merupakan faktor yang melekat pada diri seseorang yang selalu dibawa oleh manusia tersebut kapanpun dan dimana pun dia berada. Setiap individu memiliki karakteristik fisik dan psikis yang berbeda dalam individual yang lain.

Kemampuan untuk memahami yang sesungguhnya tentang diri sendiri merupakan salah satu faktor yang penting dalam menghadapi berbagai aktivitas hidup. Pemahaman diri dalam kelanjutan pendidikan sangat penting dipahami oleh masing-masing siswa, karena merupakan penentu keberhasilan masa depan mereka.

Faktor lain yang dapat mempengaruhi minat siswa SMP untuk melanjutkan ke SMK adalah faktor lingkungan para siswa SMP dari mulai lingkungan keluarga, dimana SMK menjadi sekolah turunan dari saudara tertua dan seterusnya melanjutkan ke SMK 
sehingga SMK menjadi tidak asing lagi dalam lingkungan keluarga. Pengaruh teman sebaya, karena mengikuti teman sekelas dimana pada saat masih dikelas IX SMP mereka berencana untuk bersama-sama melanjutkan ke SMK.

Masalah lain adalah prestasi akademik yang dimiliki siswa itu sendiri, beberapa siswa yang memiliki nilai akademik dibawah ratarata beranggapan bahwa SMK adalah Sekolah yang aman untuk melanjutkan pendidikannya karena mereka tidak perlu bersaing dengan siswa lain yang nilainya diatas rata-rata jika melanjutkan pendidikan ke SMA. Hingga pengaruh lingkungan sekitar tempat tinggal, hal ini bisa saja terjadi ketika mayoritas lingkungan tempat tinggal lebih banyak melajutkan pendidikan ke SMK sehingga secara tidak langsung menciptakan opini bahwa SMK lebih diminati.

Penelitian mengetahui bagaimanakah minat siswa SMP, pemahaman diri, lingkungan, dan citra SMK di Kota Pontianak untuk melanjutkan studi ke SMK, bagaimanakah pengaruh pemahaman diri terhadap minat siswa SMP untuk melanjutkan studi ke SMK, bagaimanakah pengaruh lingkungan terhadap minat siswa SMP untuk melanjutkan studi ke SMK, bagaimanakah Pengaruh citra SMK terhadap minat siswa SMP untuk melanjutkan studi ke SMK, bagaimanakan pengaruh pemahaman diri, lingkungan dan citra SMK bersama-sama terhadap minat Siswa SMP masuk SMK.

\section{Sekolah Menengah Kejuruan}

Sekolah Menengah Kejuruan adalah salah satu jenjang pendidikan menengah dengan kekhususan mempersiapkan lulusannya untuk siap bekerja.Pendidikan kejuruan mempunyai arti yang bervariasi namun dapat dilihat suatu benang merahnya. Pendidikan kejuruan yang di kembangkan di Indonesia dirancang untuk menyiapkan peserta didik atau lulusan yang siap memasuki dunia kerja dan mampu mengembangkan sikap profesional di bidang kejuruan. Para lulusan SMK di harapkan menjadi individu yang produktif yang dapat bekerja menjadi tenaga kerja menengah dan memiliki kesiapan untuk menghadapi persaingan di dunia kerja.
Pavlova (2009, 5) mendekripsikan pendapat Sanders dan Stevenson tentang pendidikan kejuruan bahwa pendidikan kejuruan berkaitan erat dengan keterampilan menggunakan alat atau mesin, pendidikan kejuruan diidentifikasi pada asumsi dikotomi yaitu pengetahuan umum lawan pengetahuan khusus; pengetahuan teori lawan praktek; pemahaman konsep lawan pemikiran keterampilan; kemampuan kreatif lawan kemampuan reproduktif, keterampilan intelektual lawan kemampuan fisik; persiapan untuk hidup lawan persiapan untuk bekerja.

Menurut Clarke \& Winch (2007, 9) mendefinisikan pendidikan kujuruan adalah pendidikan yang menyiapkan anak-anak muda dan remaja untuk memasuki lapangan kerja, pendidikan kejuruan adalah suatu proses yang mempelajari berkaitan dengan masalah teknik dan praktik. Masih menurut Clarke \& Winch ( 2007, 62) pendidikan kejuruan merupakan upaya pengembangan sosial ketenagakerjaan, pemeliharaan, percepatan dan peningkatan kualitas tenaga kerja tertentu dalam rangka peningkatan produktivitas masyarakat.

\section{Minat Siswa}

Crow \& Crow dalam Mangal $(2007,351)$ menyatakaan bahwa minat merupakan daya gerak yang mendorong seseorang untuk memberikan perhatian terhadap orang, objek atau kegiatan atau dengan kata lain alasan mengapa seseorang memberi perhatian dan berpartisipasi lebih terhadap objek atau kegiatan. Selanjutnya Manggal $(2007,352)$ menyatakan bahwa : minat berkaitan erat dengan faktor pendorong dalam diri seseorang yang membantu orang tersebut melakukan aktivitas-aktivitas yang sesuai. Minat tersebut sangat berkaitan erat dengan masalah keinginan, motif, dorongan dan kebutuhan-kebutuhan dasar.

\section{Cara Menumbuhkan Minat}

Menurut Baharuddin \& Wahyuni (2009, 24), cara untuk membangkitkan minat belajar siswa antara lain pertama, dengan membuat materi yang akan dipelajari semenarik mungkin dan tidak membosankan, baik dari bentuk buku materi, desain pembelajaran yang membebaskan siswa untuk mengeksplor apa yang dipelajari,melibatkan seluruh domain belajar 
siswa (kognitif, afektif, psikomotorik) sehingga siswa menjadi aktif. Kedua, pemilihan jurusan atau bidang studi dipilih sendiri oleh siswa sesuai dengan minatnya.

\section{Faktor-Faktor Yang Memepengaruhi Minat}

Ada beberapa faktor-faktor yang mempengaruhi minat siswa memilih SMK, diantaranya: (1). Kemauan, kemauan adalah suatu kegiatan yang menyebabkan seorang manusia sanggup melakukan berbagai tindakan yang perlu untuk mencapai tujuan tertentu. Kemauanadalahhalyangpentingkarena dengan adanya kemauan merupakan salah satu faktor penggerak seseorang untuk mau melakukan sesuatu seperti dalam hal memilih sekolah. (2). ketertarikan adalah perasaan senang, terpikat, menaruh minat kepada sesuatu.Pada saat ada ketertarikan timbul dalam diri seseorang maka ada daya juang dalam mencapai atau meraih yang ingin dicapai.Dengan adanya ketertarikan dari siswa untuk sekolah di SMK maka siswa tersebut mempunyai minat untuk masuk SMK. (3). Lingkungan Keluarga, berkaitan dengan pendidikan di lingkungan keluarga, bahwa keluarga merupakan lingkungan pendidikan pertama dan utama. Bahwa proses pendidikan di lingkungan keluarga dapat mempengaruhi kepribadian anak sebagai anak didik di dalam anggota keluarga. Karena orang tua adalah sebagai orang dewasa yang mendidik anak-anak di lingkungan keluarga di rumah, maka menjadi faktor penting bagi orang tua terhadap perkembangan kedewasaan anak untuk memahami tentang pribadi anak sebagai individu yang tumbuh dan berkembang, melalui perhatian orang tua terhadap masa depan anak, dengan pemberian wawasan terutama tentang pendidikan, sehingga adanya harapan orangtua terhadap anak untuk diarahkan sesuai dengan kebutuhan dan keadaan sosial yang sedang berlangsung. Orang tua merupakan pendidik pertama dan sebagai tumpuan dalam bimbingan kasih sayang yang utama.Maka orang tualah yang banyak memberikan pengaruh dan warna kepribadian terhadap seorang anak. Dengan demikian mengingat pentingnya pendidikan di lingkungan keluarga, maka pengaruh di lingkungan keluarga terhadap anak dapat mempengaruhi apa yang diminati oleh anak.
(4). Lingkungan Sekolah, proses pendidikan terhadap siswa di sekolah menjadi tanggung jawab guru. Pendidikan di sekolah berperan membantu orang tua di lingkungan keluarga dalam melakukan pembinaan kepada peserta didik yang dibawa dari keluarganya. Jadi pada dasarnya yang berpengaruh terhadap perkembangan siswa yaitu proses pendidikan di sekolah yang digunakan sebagai bekal untuk diterapkan dalam kehidupan di lingkungan masyarakat. Seorang guru dalam proses pendidikanjuga dapat memberikan motivasidan dorongan kepada siswa dalam menumbuhkan minatnya. Sebagai pendidik dalam lembaga pendidikan formal di sekolah maka secara langsung seorang guru telah menerima kepercayaan dari masyarakat untuk memangku jabatan dan tanggung jawab pendidikan. Jabatan seorang pendidik adalah suatu tugas yang mulia, karena guru merupakan panutan semua orang untuk mencerdaskan kehidupan bangsa, apalagi yang dibutuhkan orang pada dasarnya adalah kearah pengembangan kualitas sumber daya manusia (SDM) yang berguna. Oleh karena itu peran seorang guru dalam kehidupan sehari-hari sangat menentukan bagi kelangsungan hidup anak didik (siswa) dalam proses pendidikan. (5). Kondisi Sekolah, kondisi sekolah juga dapat mempengaruhi minat siswa dalam memilih sekolah.Faktorfaktor tersebut mempengaruhi besarnya minat yang timbul dari diri seseorang terhadap suatu objek sehingga masing-masing faktor tersebut memiliki peran yang berbeda sesuai dengan kondisi masing-masing. Ada kalanya salah satu faktor sangat dominan di dalam meningkatkan minat seseorang, sedangkan faktor yang lain tidak terlalu dominan. Hal ini dipengaruhi oleh kondisi masing-masing individu yang tentunya antara individu yang satu dengan yang lain berbeda(Suprapto dalam B.Restiono, 2013, 16).

\section{Pentingnya Minat}

Minat pada dasarnya adalah penerimaan akan suatu hubungan antara diri sendiri dengan sesuatu di luar diri. Minat berhubungan dengan gaya gerakyang mendorong seseorang untuk menghadapi atau berurusan dengan orang, benda,kegiatan, pengalaman yang dirangsang oleh kegiatan itu sendiri (Djaali, 2008, 34). 


\section{Minat Siswa SMP masuk SMK}

Menurut Buhler dalam Sobur $(2003,131)$ menyatakan bahwa, masa remaja termasuk tahap "explorasi"pada tingkat tentative (usia 9 19 tahun) memasuki fase keempat dan kelima remaja dimana faktor yang diperhitungkan atau dipertimbangkan adalah kebutuhan, minat, kapasitas, dan nilai-nilai kesempatan. Pilihan tentative ini seyogyanya dibuat dan diuji baik dari fantasi,diskusi,kursus-kursus maupun bekerja.

Pada tahap tentative anak-anak mulai menyadari memiliki minat dan kemampuan yang berbeda satu sama lain. Ada yang lebih berminat di bidang teknologi, sedamgkan ada yang lebih bermiat bisnis dan manajamen, maupun seni dan olah raga.Demikian juga anak-anak mulai sadar bahwa kemampuannya berbeda satu sama lain. Ada yang lebih mampu dibidang matematika dan IPA sedang yang lain dalam bidang bahasa dan IPS ataupun lainnya. Untuk memwujudkan cita-cita karir anak antara lain dimulai dari pemilihan dan penentuan jenis pendidikan tersebut sangat berkaitan dengan bidang keahlian yang dimiliknya.

Gumbiner (2003, 18) menjelaksan bahwa siswa-siswi kelas IX SMP pada masa ini mengalami perkembangan mencapai kematangan fisik, mental, emosional dan social. Karena berada pada masa peralihan antara masa anak-anak dan masa dewasa, maka status remaja agak kabur,baik bagi dirinya maupun bagi lingkungannya.pengertian ini juga ditegaskan oleh Semiawan DKK menjelaskan bahwa siswa-siswi kelas IX SMP merupakan masa remaja yang merupakan masa peralihan antara masa anak dan masa dewasa.

\section{Pemahaman Diri}

Manusia sejak dalam kandungan merupakan mahluk hidup yang bergerak menuju kematangan diri.Setelah lahir manusia itu terus tumbuh dan berkembang.Proses yang demikian berlangsung terus menerus sampai akhir hayat.Tujuan pertumbuhan dan perkembangan manusia adalah kematangan diri sebagai perwujudan penemuan dirinya. Proses kematangan ini berlangsung dalam situasi interaksi antara dirinya dengan orang lain ditengah masyarakat.
Pemahaman diri (self knowledge) merupakan faktor yang melekat pada diri seseorang yang selalu dibawa oleh manusia tersebut kapanpun dan dimana pun dia berada. Setiap individu memiliki karakteristik fisik dan psikis yang berada dalam individual yang lain. Kemampuan untuk memahami yang sesungguhnya tentang diri sendiri merupakan salah satu faktor yang penting dalam menghadapi berbagai aktivitas hidup.

Menurut Santrock dalam Tizar (2010, 12) adalah gambaran kognitif remaja mengenai dirinya, dasar dan isi dari konseo diri remaja,namun lebih merupakan konstruksi kognisi sosialnya. Pada masa remaja persinggungan antara penggalaman sosial, budaya dan norma yang berlaku mempengaruhi pada kognisi sosial remaja, penting untuk mengetahui kesadaran diri.

\section{Citra SMK}

Citra adalah image atau kesan yang kuat melekat pada seseorang, kelompok atau tentang suatu institusi. Citra sekolah merupakan suatu hubungan dengan kesan maupun presepsi pada suatu objek atau benda sehingga menimbulkan suatu kesan atau nilai pada orang yang melihat atau menyandangnya. Seperti citra seorang guru yang baik, maka sebenarnya yang dimaksud adalah kesan atau penilaian atau sifat- sifat atau kenampakan perilaku guru yang baik sesuai kode etik guru atau kebudayaan masyarakat tertentu.

Citra SMK adalah kesan atau penilaian orang-orang terhadap prilaku orang, keadaan lingkungan,dan lain-lain yang berhubungan dengan keberadaan suatu SMK.

Sudji Munadi (2006, 51) menjelaskan bahwa adanya suatu budaya sekolah yang harmonis tentu akan menumbuhkan interaksi yang baik dan positif antar komponen yang terkait dalam masyarakat sekolah. Kultur sekolah yang baik akan memberikan dampak yang langsung dan mendalam pada prilaku dan performa sekolah tersebut dengan kata lain bahwa sekolah yang berhasil memperoleh prestasi dalam penyelengaraan pendidikan dan pengajaran karena didukung oleh kultur sekolah yang baik.Siswa yang belajar di sekolah yang kulturnya baik maka memungkinkan timbulnya respon psikologis. 


\section{Lingkungan}

Dalam kamus besar bahasa indonesia (KBBI) lingkungan adalah daerah kawasan yang termasuk didalamnya; golongan; kalangan; dimana ia berasal; semua yang memengaruhi pertumbuhan manusia (KBBI, 831).

Sartain dalam Purwanto $(2012,28)$ mengatakan bahwa yang dimaksud dengan lingkungan (environment) ialah meliputi semua kondisi-kondisi dalam dunia ini yang dalam cara-cara tertentu mempengaruhi tingkah laku kita, perkembangan atau life processes kita kecuali gen-gen, dan bahkan gen-gen dapat pula dipandang sebagai menyiapkan lingkungan (to provide environment) bagi gen yang lain.

Menurut Bimba dan Mishra (2012:43) keluarga sangat berpariasi dalam struktur dan fungsi, variasi tersebut ada di sekolah dan ada pada siswa itu sendiri. Mengingat keragaman ini dalam keluarga, ada kebutuhan untuk memahami bagaimana pengalaman anak-anak dalam keluarga, ada kebutuhan untuk memahami bagaimana pengalaman anak-anak dalam keluarga berkontribusi terhadap hasil pendidikan mereka.

\section{Latar Belakang Ekonomi Keluarga}

London (1973, 93) menyatakan penting untuk mengetahui kedudukan ayah, dan penting juga untuk mengetahui pekerjaan ibu, dan apakah mereka melakukan itu secara teratur atau memiliki pekerjaan tetap. Dengan informasi tersebut, konselor bisa mendapatkan gambaran umum dari status ekonomi keluarga. Keadaan ekonomi keluarga erat hubungannya dengan belajar anak, terkait dengan kebutuhan pokok misalnya makan, pakaian, perlindungan kesehatan, fasilitas belajar: ruang belajar, meja, kursi, penerangan, alat tulis, buku, dan lainlain. Penghasilan orang tua juga dipengaruhi oleh pendidikan orang tua.Semakin tinggi pendidikannya, semakin banyak alternatif pekerjaan yang bisa dipilih, yang tentu saja dapat meningkatkan kesejahteraan keluarga. Karena orang tua sebagai pencari nafkah bagi keluarganya, maka orang tua lah sebagai pengatur kebutuhan keluarga, termasuk pendidikan anak-anaknya.

Dalam menentukan pendidikan anakanaknya, orang tua merupakan daya dukung yang sangat kuat. Penghasilan orang tua juga menentukan alokasi dana untuk anaknya, Kekayaan pribadi saat ini juga dikaitkan dengan kemampuan untuk memenuhi biaya pendidikan, dan melalui mekanisme ini, kendala keuangan diyakini secara langsung membatasi kesempatan pendidikan yang lebih tinggi dari sosial ekonomi kurang beruntung (McMillan \& Western 2000).

Roucek \& Warren dalam Sudji Munadi (2006) menyatakanOrang tua merupakan bagian anggota keluarga yang peranannya sangat dominan dalam pembentukan kepribadian anak. Status ekonomi orang tua dalam masyarakat akan mempengaruhi seseorang siswa pada hampir seluruh variabel seperti tingkat kesanggupan, perkembangan intelegensi, aspirasi motivasi, konsep diri, persetasi dan sebagainya. Status sosial ekonomi selalu mengacu kepada kedudukan khusus seseorang dalam masyarakat berhubungan dengan orang dalam lingkungan yang disertainya, martabat yang diperolehnya, dan hak serta tugas yang dimilikinya.

Weinger dalam Rice \& Dolgin $(2008,380)$ status sosial ekonomi cenderung mempengaruhi pemuda dalam memiliki pengetahuan dan pemahaman pekerjaan. Orang tua dengan status sosial ekonomi menengah, lebih mampu dari orang tua yang berasal dari status sosial ekonomi lebih rendah untuk mengembangkan minat kejuruan yang luas dan kesadaran untuk mencari peluang di masyarakat setempat. Remaja dari keluarga yang status sosial ekonomi rendah cenderung kurang dalam memandang sesuatu, kurang membaca, kurang informasi, dan kurang variasi pengalaman di lingkungan mereka secara umum dan memiliki peluang lebih sedikit dibandingkan dengan pemuda dari tingkat status sosial ekonomi yang lebih tinggi.Akibatnya, remaja dengan status sosial ekonomi rendah cenderung untuk mengambil pekerjaan hanya mereka tahu tentang ketikamereka memasuki pasar tenaga kerja.Latar belakang social ekonomi dan budaya pemuda mempengaruhi pengetahuan pekerjaan dan preferensi pekerjaan mereka.

\section{Kultur Kelurga}

Faktor orang tua sangat besar pengaruhnya terhadap keberhasilan anak dalam belajar. 
Tinggi rendahnya pendidikan orang tua, besar kecilnya penghasilan, cukup atau kurang perhatian dan bimbingan orang tua,rukun atau tidaknya kedua orang tua, akrab atau tidaknya hubungan orang tua dengan anak-anaknya, tenang atau tidaknya situasi dalam rumah, semuanya itu turut mempengaruhi pencapaian hasil belajar anak. Di samping itu, faktor keadaan rumah juga turut mempengaruhi keberhasilan belajar. Besar kecilnya rumah, tempat tinggal, ada atau tidaknya peralatan/media belajar seperti papan tulis, gambar, peta, ada atau tidak kamar atau meja belajar, dan sebagainya, semuanya itu juga turut menentukan keberhasilan belajar seseorang (Dalyono,1997, 59).

Berikut adalah faktor keluarga yang dapat mempengaruhi belajar menurut Slameto (2010, 60) diantaranya cara orang tua mendidik, cara orang tua mendidik anak memiliki pengaruh yang besar terhadap belajar anak. Hal ini dipertegas oleh Sutjipto Wirodjojo dalam Slameto $(2010,61)$ yang menyatakan bahwa keluarga adalah lembaga pendidikan yang pertama dan utama.Keluarga yang sehat besar artinya untuk pendidikan dalam ukuran kecil, tetapi bersifat menentukan untuk pendidikan dalam ukuran besar yaitu pendidikan bangsa, negara dan dunia.

Selanjutnya Suasana Rumah, suasana rumah dimaksudkan sebagai situasi atau kejadian-kejadian yang sering terjadi didalam keluarga dimana anak berada dan belajar. Suasana rumah juga merupakan faktor yang penting dalam menunjang hasil belajar anak.Agar anak dapat belajar dengan baik perlulah diciptakan suasana rumah yang tenang dan tentram.

Berdasarkan uraian diatas dapat disimpulkan bahwa lingkungan adalah tempat dimana tumbuh dan berkembangnya seorang individu dalam memenuhi kebutuhan hidupnya kultur keluarga adalah gambaran situasi dalam keluarga termasuk hubungan antar anggota keluarga, keadaan rumah, perhatian dan bimbingan keluarga. Keluarga merupakan pusat pendidikan yang utama dan pertama dimana hal tersebut akan mempengaruhi kepribadian dan pendidikan lanjut anak-anaknya setelah SMP.

\section{Kerangka Berpikir}

Minat selalu ada dalam kehidupan sebagai awal untuk melaksanakan sesuatu dengan di- tandai rasa senang atau tidak senang, suka atau tidak suka terhadap suatu kegiatan,pekerjaan atau situasi. Minat siswa SMP melanjutkan ke SMK tidak terbentuk dengan sendirinya tetapi melalui pergaulan dan merupakan hasil belajar, dalam perkembangannya akan mengenal dunia sekitarnya, menerima informasi dari orang tua. Masyarakat disekitar tempat tinggal, teman bermain dan teman sekolah, sosialisasi dan promosi yang diterima, serta guru yang akan membentuk pola baru dalam berpikir .

Besarnya masukan input SMK pada dasarnya tergantung kepada besarnya minat lulusan SMP untuk melanjutkan ke SMK. Makin besar minat siswa SMP melanjutkan studi ke SMK maka makin besar pula jumlah siswa dan lulusan SMK. Dalam penelitian ini, variabel pemahaman diri, lingkungan dan citra SMK sebagai variabel bebas. Ketiga varibel tersebut diduga mempengaruhi minat siswa SMP masuk SMK sebagai variabel terikat baik secara langsung maupun tidak langsung.

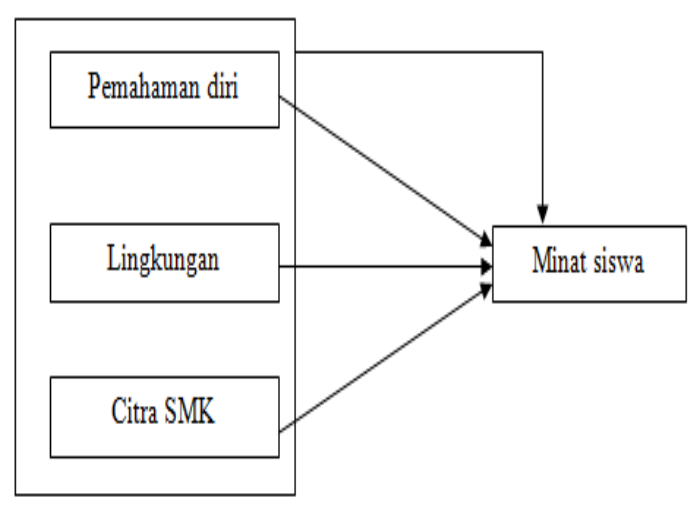

Gambar 1. Kerangka Berpikir

\section{METODE PENELITIAN}

Penelitian tentang "faktor-faktor yang memengaruhi minat siswa SMP masuk SMK di kota Pontianak" menggunakan:

\section{Jenis Penelitian}

Penelitian ini menggunakan pendekatan kuantitaif dengan jenis penelitian yaitu $e x$ post facto.

\section{Waktu dan Tempat Penelitian}

Penelitian dilakukan di 12 Sekolah SMP Negeri dan SMP Swasta yang ada di enam Ke- 
camatan kota Pontianak dilakukan pada bulan Februari 2014 sampai dengan April 2014.

\section{Populasi dan Sampel Penelitian}

Populasi penelitian ini adalah siswa kelas IX SMP pada Kota Pontianak. Tahun ajaran 2013-2014. Memilih siswa kelas IX karena para siswa dalam tingkat ini benar-benar sudah dihadapkan pada pilihan untuk melanjutkan sekolah, dengan pilihan apakah ke SMA, MA, SMK atau terpaksa berhenti sekolah karena alasan tertentu. mengambil sampel atau mengambil bagian populasi atau yang mewakili (representasi) populasi. Ini berarti tidak semua anggota populasi dan hanya bagian saja yang dianggap mewakili untuk diikut sertakan dalam proses penelitian. Sampel penelitian ini ditentukan dengan teknik cluster random sampling. Sampling acak yang dilakukan berturut-turut terhadap unit-unit atau himpunan-himpunan bagian

Sampilng kelompok merupakan metode yang cocok digunakan untuk cakupan populasi yang luas dan kondisinya yang sangat beragam. Dasar logis penentuan cluster adalah area atau daerah yang meliputi Kecamatan Pontianak Selatan, Kecamatan Pontianak Timur, Kecamatan Pontianak Barat, Kecamatan Pontianak Utara, Kecamatan Pontianak kota,dan Kecamatan Pontianak Tenggara. Pengambilan sampel dilakukan dengan mengelompokan sekolah, dalam hal ini dikelompokkan menjadi SMP Negeri dan SMP Swasta.

Berdasarkan data yang diambil dari Diknas kota Pontianak terdapat 24 SMP Negeri dan 47 SMP Swasta. Penentuan ukuran sampel menggunakan tabel Issac \& Michael dengan tingkat kesalahan 5\%. Berdasarkan tabel tersebut ditetapkan sampel penelitian sebanyak 350 siswa. Pengambilan sampel penelitian ditentukan dengan teknik proportional random sampling. Proportional berarti dari setiap siswa SMP yang terpilih, diambil sampel individu dengan memperhatikan proporsi siswa masing-masing daerah populasi. Random sampling berarti pengambilan sampel individu dengan cara di undi/acak sehingga setiap siswa mempunyai kesempatan yang sama untuk menjadi sampel penelitian. Dan hanya akan digunakan 2 sekolah pada 1 Kecamatan, masing-masing 1 SMP Negeri dan 1 SMP Swasta.

Sampel penelitian ini adalah seluruh siswa SMP Kelas IX di Kota Pontianak, yang tersebar dalam 6 wilayah Kecamatan yakni, pada masing Kecamatan diwakili 2 SMP. Kecamatan Pontianak Barat sekolah yang mewakili SMP Negeri 16 dan SMP Swasta Koperasi, Pontianak Kota sekolah yang mewakili SMP Negeri 19 dan SMP Swasta Bina Utama, Pontianak Selatan sekolah yang mewakili SMP Negeri 2 dan SMP Swasta LKIA Pontianak, Pontianak Timur SMP Negeri 21 dan SMP Swasta PGRI 04, Pontianak Utara Sekolah yang mewakili SMP Negeri 20 dan SMP Swasta ISLAM AL-ASY'ARIYYAH dan Pontianak Tenggara sekolah yang mewakili SMP Negeri 8 dan SMP Swasta ISLAMIYAH.

\section{Teknik dan Instrumen Pengumpulan Data}

Teknik pengumpulan data penelitian menggunakan angket tertulis/ kuesioner untuk mengumpulkan data identitas siswa dengan cara membagikan angket berisi butirbutir pertanyaan atau pernyataan instrumen penelitian tehadap responden, yang diperlukan dari semua variabel yang diteliti yaitu minat, pemahaman diri, lingkungan dan citra SMK.

Instrumen pengumpulan data berupa angket yang disusun dengan skala Likrt, yang bersifat closed ended questioner atau kuesioner tertutup. Sumber data diperoleh dari siswa kelas IX SMP Negeri dan Swasta yang tersebar di enam Kecamatan.

\section{Teknik Analisis Data}

Analisis data adalah proses pengolahan data penelitian. Analisis data yang digunakan pada penelitian ini, yaitu statistik deskriptif, dan statistik inferensial. Analisis deskriptif ditabulasikan dengan mengetahui nilai maksimun, nilai minimum, nilai rerata(mean), nilai tengah (median), nilai yang Paling sering muncul (modus), standar deviasi, varians, dan range nilai pada masing-masing variabel, baik variabel dependen maupun variabel independen. 


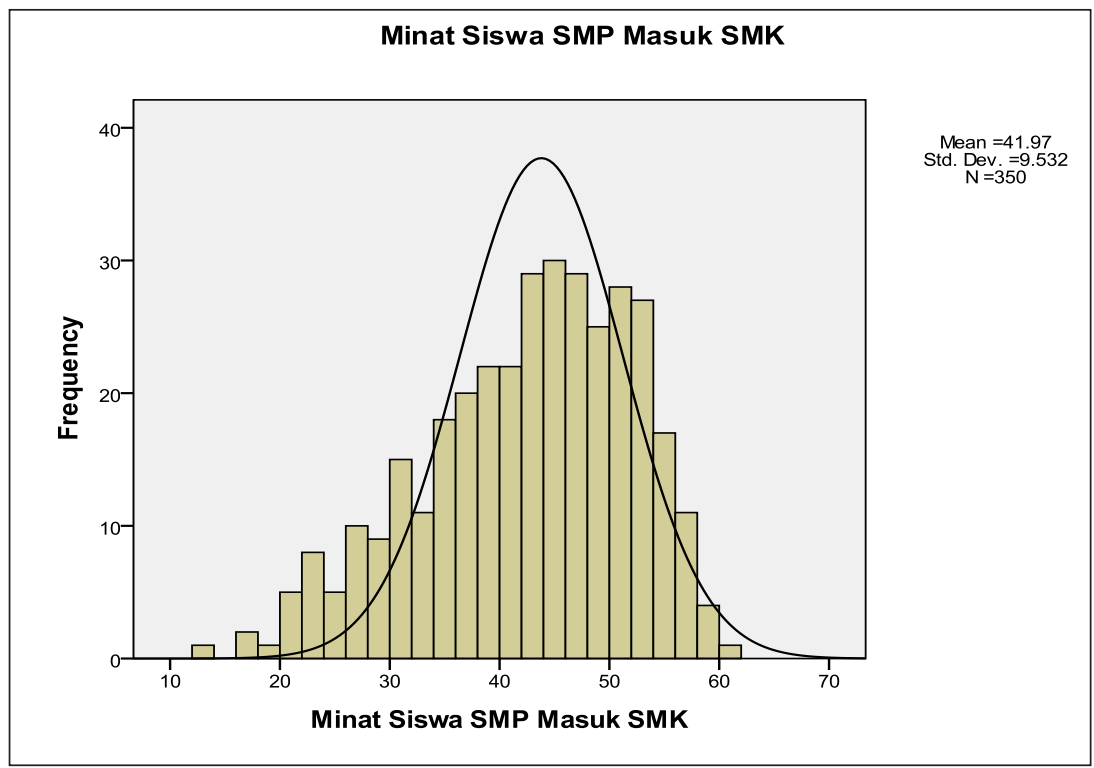

Gambar 2. Histogram Minat

\section{Uji Analisis Data}

Uji persyaratan analisis dimaksud untuk mengetahui apakah data yang dikumpulkan telah memenuhi syarat untuk dianalisis dengan teknik analisis yang yang direncanakan. Hal ini dilakukan agar dalam analisis selanjutnya tidak mengalami hambatan dan sesuai dengan teknik analisis yang direncanakan. Untuk teknik analisis regresi ganda memerlukan beberapa syarat, yakni variabel terikat mengikuti sebaran normal baku, variabel bebas dan variabel terikat memiliki korelasi linier, dan antara sesama variabel bebas korelasinya tidak terlalu tinggi.

\section{HASIL PENELITIAN DAN PEMBAHASAN}

Penelitian yang telah diselesaikan, selanjutnya dihitung dan analisis untuk menjawab hipotesis penelitian. Perhitungan penelitian menggunakan analisis deskriptif untuk mengetahui gambaran dari variabel penelitian, dan analisis inferensial untuk mengetahui besarnya pengaruh dari tiap-tiap variabel penelitian.

\section{Analisis Deskriptif}

Berikut gambaran umum dari variabel minat, pemahaman diri, lingkungan, dan citra SMK.

\section{Minat}

Berdasarkan penelitian yang dilakukan pada siswa SMP di Kota Pontianak didapatkan hasil bahwa minat siswa yang memiliki kecendrungan kategori sangat baik sebesar $30,0 \%$, yang memiliki kecendrungan kategori baik sebesar $31,1 \%$, yang memiliki kecendrungan kategori cukup sebesar 21,1\%, yang memiliki kecendrungan kategori kurang sebesar $12,0 \%$, yang memiliki kecendrungan kategori sangat kurang sebesar 5,7\%. Hal ini menunjukan bahwa minat siswa SMP di Kota Pontianak termasuk dalam kategori baik. Berdasarkan jawaban tersebut diperoleh hasil analisis Nilai minimun di perolah sebesar 18 , maksimal sebesar 55, mean sebesar 39,60, median sebesar 40,00, modus sebesar 40dan satandar deviasi sebesar 6,575.

\section{Pemahaman Diri}

Berdasarkan penelitian yang dilakukan pada siswa SMP di Kota Pontianak didapatkan hasil bahwa pemahaman diri terhadap minat siswa SMP yang memiliki kecendrungan pada kategori sangat baik sebesar 22,0\%, yang memiliki kecendrungan kategori baik sebesar $45,4 \%$, yang memiliki kecendrungan kategori cukup sebesar $26,3 \%$, yang memiliki kecenderungan kategori kurang sebesar 5,7\%, yang memiliki kecendrungan sangat kurang sebesar 


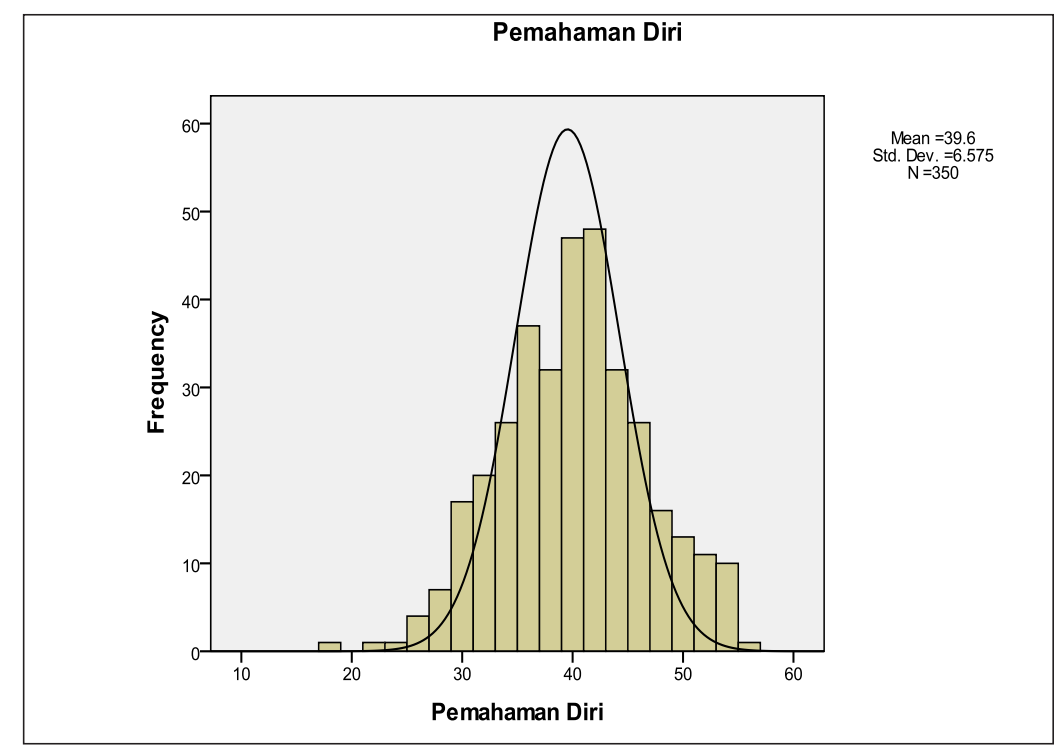

Gambar 3. Histogram Pemahaman diri

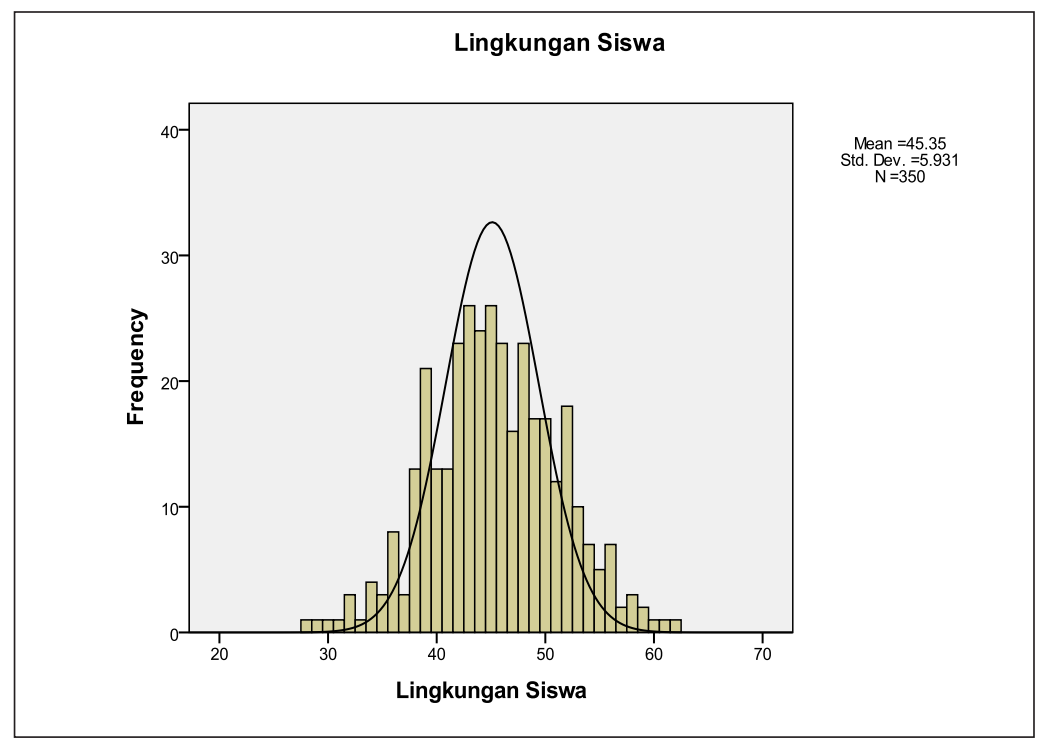

Gambar 4. Histogram Lingkungan

6\%. Hal ini menunjukan bahwa pemahaman diri terhadap minat siswa SMP masuk SMK di Kota Pontianak termasuk dalam kategori baik. Nilai minimun di perolah sebesar 18 , maksimal sebesar 55, mean sebesar 39,60, median sebesar 40,00, modus sebesar 40dan satandar deviasi sebesar 6,575. Distribusi frekuensi pemahaman diri terhadap minat dilihat dalam gambar dibawah ini.

\section{Lingkungan}

Berdasarkan data yang peroleh hasil bahwa lingkungan terhadap minat melanjutkan ke SMK yang memiliki kategori sangat baik sebanyak 39 siswa atau 11,1\%, kategori baik sebanyak 176 siswa atau 50,3\%, kategori cukup sebanyak 123 siswa atau 35,1\%, kategori kurang sebanyak 12 siswa atau $6 \%$, kategori sangat kurang sebanyak 0 siswa, jadi secara keseluruhan faktor lingkungan pada minat siswa SMP masuk SMK mempunyai kecendrungan baik. Nilai minimum yang diperoleh sebesar 28 , nilai maksimum sebesar 62 ,mean sebesar 39,60, median sebesar 45,35, modus sebesar 43 dan standar deviasi sebesar 5,931. Distribusi frekuensi lingungan terhadap minat dilihat dalam gambar 4. 


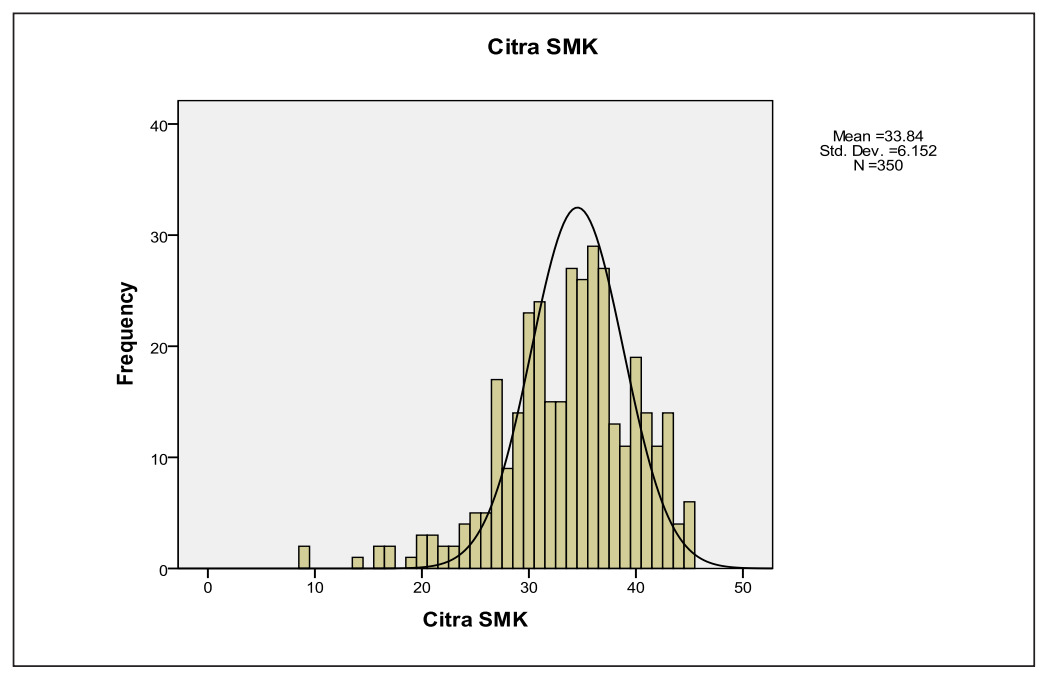

Gambar 5. Histogram Citra SMK.

\section{Citra SMK}

Berdasarkan data yang peroleh hasil bahwa Citra SMK terhadap minat siswa masuk ke SMK dengan kategori sangat baik sebanyak 119 siswa atau 34,0\%, kategori baik sebanyak 136 siswa atau 38, 9\%, kategori cukup sebanyak 73 siswa atau 20,9\%, kategori kurang sebanyak 15 siswa atau 4,3\%, kategori sangat kurang sebanyak 7 siswa atau 2,0\%, jadi secara umum citra SMK terhadap minat siswa masuk SMK mempunyai kecendrungan kategori baik. Nilai minimum yang diperoleh sebesar 9 , nilai maksimum sebesar 45, mean sebesar 33,84, median sebesar 34,00, modus sebesar 36 dan standar deviasi sebesar 6,152. Distribusi frekuensi citra SMK dapat dilihat pada gambar 5.

\section{Pengujian Hipotesis}

Untuk mengetahui pemahaman diri terhadap minat siswa SMP digunakan analisis regresi linear sederhana. Berikut ini adalah hasil analisis linear sederhana untuk pengaruh pemahaman diri $\left(\mathrm{X}_{1}\right)$ terhadap minat siswa (Y). Untuk mengukur besarnya sumbangan variabel pemahaman diri terhadap variasi naik turunya variabel minat siswa.Koefisien korelasi antara pemahaman diri terhadap minat siswa sebesar 0,753 yang artinya terdapat hubungan antara pemahaman diri terhadap minat siswa. Koefisien Determinasi $(\mathrm{KD})=(0,753)^{2}=0,567$ atau $56,7 \%$ yang artinya pemahaman diri memberikan pengaruh sebesar $56,7 \%$ terhadap minat siswa sedangkan $43,3 \%$ dipengaruhi variabel lain yang tidak diteliti.

Untuk mengetahui lingkungan terhadap minat siswa SMP digunakan analisis regresi linear sederhana. Berikut ini adalah hasil analisis linear sederhana untuk pengaruh lingkungan $\left(\mathrm{X}_{2}\right)$ terhadap minat siswa ( $\mathrm{Y}$ ). Untuk mengukur besarnya sumbangan variabel pemahaman diri terhadap variasi naik turunya variabel minat siswa. Koefisien korelasi antara lingkungan terhadap minat siswa sebesar 0,527 yang artinya terdapat hubungan antara lingkungan terhadap minat siswa. Koefisien Determinasi $(\mathrm{KD})=(0,527)^{2}=0,277$ atau $27,7 \%$ yang artinya linkungan memberikan pengaruh sebesar $27,7 \%$ terhadap minat siswa sedangkan $43,3 \%$ dipengaruhi variabel lain yang tidak diteliti.

Untuk mengetahui citra SMK terhadap minat siswa SMP digunakan analisis regresi linear sederhana. Berikut ini adalah hasil analisis linear sederhana untuk pengaruh Citra SMK $\left(\mathrm{X}_{3}\right.$ ) terhadap minat siswa ( $\mathrm{Y}$ ). Untuk mengukur besarnya sumbangan variabel citra SMK terhadap variasi naik turunya variabel minat siswa. Koefisien korelasi antara citra SMK terhadap minat siswa sebesar 6,78 yang artinya terdapat hubungan antara citra SMK terhadap minat siswa. Koefisien Determinasi $(\mathrm{KD})=(0,678)^{2}=0,459$ atau $45,9 \%$ yang artinya lingkungan memberikan pengaruh sebesar $45,9 \%$ terhadap minat siswa sedangkan $54,1 \%$ dipengaruhi variabel lain yang tidak diteliti. 
Tabel 1. Correlations

\begin{tabular}{|c|c|c|c|c|c|}
\hline & & $\begin{array}{c}\text { Minat Siswa SMP } \\
\text { Masuk SMK }\end{array}$ & $\begin{array}{c}\text { Pemahaman } \\
\text { Diri }\end{array}$ & $\begin{array}{l}\text { Lingkungan } \\
\text { Siswa }\end{array}$ & $\begin{array}{l}\text { Citra } \\
\text { SMK }\end{array}$ \\
\hline Minat Siswa SMP & Pearson & 1 & $.753^{* *}$ & $.527^{* *}$ & $.678^{* *}$ \\
\hline \multirow[t]{3}{*}{ Masuk SMK } & Correlation & & & & \\
\hline & Sig. (2-tailed) & & .000 & .000 & .000 \\
\hline & $\mathrm{N}$ & 350 & 350 & 350 & 350 \\
\hline \multirow[t]{3}{*}{ Pemahaman Diri } & $\begin{array}{l}\text { Pearson } \\
\text { Correlation }\end{array}$ & $.753^{* *}$ & 1 & $.547^{* *}$ & $.661^{* *}$ \\
\hline & Sig. (2-tailed) & .000 & & .000 & .000 \\
\hline & $\mathrm{N}$ & 350 & 350 & 350 & 350 \\
\hline \multirow[t]{3}{*}{ Lingkungan Siswa } & $\begin{array}{l}\text { Pearson } \\
\text { Correlation }\end{array}$ & $.527^{* *}$ & $.547^{* *}$ & 1 & $.567^{* *}$ \\
\hline & Sig. (2-tailed) & .000 & .000 & & .000 \\
\hline & $\mathrm{N}$ & 350 & 350 & 350 & 350 \\
\hline \multirow[t]{3}{*}{ Citra SMK } & $\begin{array}{l}\text { Pearson } \\
\text { Correlation }\end{array}$ & $.678^{* *}$ & $.661^{* *}$ & $.567^{* *}$ & 1 \\
\hline & Sig. (2-tailed) & .000 & .000 & .000 & \\
\hline & $\mathrm{N}$ & 350 & 350 & 350 & 350 \\
\hline
\end{tabular}

**. Correlation is significant at the 0.01 level (2-tailed).

Tabel 2. Coefficients ${ }^{\mathrm{a}}$

\begin{tabular}{|c|c|c|c|c|c|c|c|c|}
\hline \multirow{2}{*}{\multicolumn{2}{|c|}{$\begin{array}{c}\text { Model } \\
\text { B }\end{array}$}} & \multicolumn{2}{|c|}{$\begin{array}{c}\text { Unstandardized } \\
\text { Coefficients }\end{array}$} & \multirow[t]{2}{*}{$\begin{array}{c}\text { Standardized } \\
\text { Coefficients }\end{array}$} & \multirow{2}{*}{$\mathbf{t}$} & \multirow{2}{*}{$\begin{array}{c}\text { Sig. } \\
\text { Tolerance }\end{array}$} & \multicolumn{2}{|c|}{$\begin{array}{c}\text { Collinearity } \\
\text { Statistics }\end{array}$} \\
\hline & & $\begin{array}{l}\text { Std. } \\
\text { Error }\end{array}$ & Beta & & & & \multicolumn{2}{|c|}{ VIF } \\
\hline \multirow[t]{4}{*}{1} & (Constant) & -8.735 & 2.507 & & -3.484 & .001 & & \\
\hline & Pemahaman Diri & .749 & .066 & .517 & 11.369 & .000 & .520 & 1.923 \\
\hline & Lingkungan Siswa & .126 & .067 & .078 & 1.893 & .059 & .626 & 1.599 \\
\hline & Citra SMK & .453 & .072 & .292 & 6.325 & .000 & .503 & 1.988 \\
\hline
\end{tabular}

a. Dependent Variable: Minat Siswa SMP Masuk SMK

\section{Regresi Ganda}

Analisis regresi linier berganda digunakan untuk menguji hipotesis guna mengetahui Pengaruh Pemahaman Diri, Lingkungan dan Citra SMK terhadap Minat Siswa SMP Masuk SMK secara bersama-sama.

Hasil analisis regresi linier berganda tersebut dimasukkan ke dalam persamaan menjadi:

$\mathrm{Y}=-8,735+0,749 \mathrm{X}_{1}+0,126 \mathrm{X}_{2} 0,453 \mathrm{X}_{3}$

Minat $=-8,735+0,749$ Pemahaman Diri + 0,126 Lingkungan + 0,453 Citra SMK Bentuk persamaan tersebut diartikan sebagai berikut: Nilai konstanta sebesar $-8,735$ menunjukan bahwa jika tidak ada variabel pemahaman diri $\left(\mathrm{X}_{1}\right)$, lingkungan $\left(\mathrm{X}_{2}\right)$, citra SMK $\left(\mathrm{X}_{3}\right)$ maka skor minat siswa $(\mathrm{Y})$ adalah sebesar-8,735. Koefisien regresi (b1) adalah sebesar 0,749 menunjukan bahwa setiap penambahan satu skor pemahaman diri $\left(\mathrm{X}_{1}\right)$ maka akan meningkatkan minat sebesar -7,986, dengan asumsi bahwa variabel lingkungan dan citra SMK dari model regresi adalah tetap, koefisien regresi (b2) sebesar 0,126 menunjukan bahwa setiap penambahan ssatu skor lingkungan $\left(\mathrm{X}_{2}\right)$ maka akan meningkatkan minat siswa $(\mathrm{Y})$ sebesar -8,609 dengan asumsi bahwa variabel pemahaman diri dan citra SMK dari model regersi adalah tetap, koefisien regresi (b3) sebesar 
Tabel 3. ANOVA ${ }^{\mathrm{b}}$

\begin{tabular}{llrllll}
\hline \multicolumn{1}{c}{ Model } & $\begin{array}{c}\text { Sum of } \\
\text { Squares }\end{array}$ & df & Mean Square & F & Sig. \\
\hline 1 Regression & 19924.841 & 3 & 6641.614 & 194.998 & $.000^{\text {a }}$ \\
Residual & 11784.747 & 346 & 34.060 & & \\
$\quad$ Total & 31709.589 & 349 & & & \\
\hline
\end{tabular}

a. Predictors: (Constant), Citra SMK, Lingkungan Siswa, Pemahaman Diri

b. Dependent Variable: Minat Siswa SMP Masuk SMK

0,453 menunjukan bahwa setiap penambahan satu skor citra SMK $\left(\mathrm{X}_{3}\right)$ maka akan meningkatkan minat siswa (Y) sebesar -8,282 dengan asumsi bahwa variabel pemahaman diri dan lingkungan dari model regresi adalah tetap.

Untuk menguji hipotesis keempat digunakan uji $\mathrm{F}$ dengan menggunakan significance level 0,05. Dari data diatas untuk diperoleh nilai signifikansi sebesar $0,000<0,05$ dan $\mathrm{F}_{\text {hitung }}$ sebesar 194,998 $>\mathrm{F}_{\text {tabe }} 1$ sebesar 1,193 sehingga dapat disimpulkan bahwa $\mathrm{H}_{0}$ ditolak dan $\mathrm{H}_{\mathrm{a}}$ diterima yang berarti terdapat pengaruh antara pemahaman diri, lingkungan dan citra SMK terhadap minat siswa SMP masuk SMK di Kota Pontianak. Hal ini menunjukan hipotesis yang menyatakan bahwa terdapat pengaruh antara pemahaman diri, lingkungan dan citra SMK terhadap minat siswa SMP masuk SMK di Kota Pontianak dapat diterima dengan tingkat kepercayaan $95 \%$, dengan demikian hipotesis ke empat pada penelitian ini dapat dibuktikan kebenaranya.

\section{SIMPULAN DAN SARAN}

\section{Simpulan}

Berdasarkan hasil analisis data pengaruh Pemahaman Diri, Lingkungan, dan Citra SMK terhadap Minat Siswa SMP Masuk SMK di Pontianak baik secara parsial maupun secara simultan, maka diperoleh kesimpulan sebagai berikut: (1) Distribusi skor variabel Minat Siswa SMP Masuk SMK mempunyai kecendrungan dalamkategori Baik dengan rata-rata nilai 41,79 , variabel pemahaman diri mempunyai kecendrungan dalam kategori baik dengan rata-rata nilai 39,60, variabel lingkungan mempunyai kecendrungan dalam kategori cukup dengan rata-rata nilai 39,60 , variabel citra SMK mempunyai kecendrungan dalam kategori baik dengan rata-rata nilai 33,84.
(2)Pemahaman Diri berpengaruh positif dan signifikan terhadap Minat Siswa SMP Masuk SMK di kota Pontianak ditunjukan dengan nilai $r=0,753 ; p=0,000$.(3) Lingkungan Siswa berpengaruh positif dansignifikan terhadap Minat Siswa SMP Masuk SMK di Kota Pontianak ditunjukan dengan nilai $\mathrm{r}=$ 0,527; $p=0,000$. (4) Citra SMK berpengaruh positif dan signifikan terhadap Minat Siswa SMP Masuk SMK di Kota Pontianak ditunjukan dengan nilai $r=0,678 ; p=0,000$. (5) Pemahaman Diri, Lingkungan Siswa, dan Citra SMK, secara bersama-sama berpengaruh positif dan signifikan terhadap Minat Siswa SMP Masuk SMK di Kota Pontianak dengan persamaan regresi $\mathrm{Y}=-8,735+0,749 \mathrm{X}_{1}+$ $0,126 \mathrm{X}_{2}+0,453 \mathrm{X}_{3}$. NilaiR ${ }^{2}$ regresi linier berganda sebesar 0,628 . Hal ini berarti ketiga variabel independen, yaitu Pemahaman Diri (X1), Lingkungan Siswa (X2), dan Citra SMK (X3) mampu menjelaskan perubahan variabel dependen Minat Siswa SMP Masuk SMK sebesar $62,8 \%$, sisanya $(37,2 \%)$ dijelaskan oleh faktor lain selain pemahaman diri, lingkungan siswa, dan citra SMK.

\section{Saran}

Berdasarkan hasil penelitian dan kesimpulan yang telah dipaparkan, maka saran yang dapat disampaikan oleh peneliti sebagai berikut :(1). Melihat minat siswa SMP untuk melanjutkan ke SMK adalah baik, maka pihak sekolah SMK yang berperan dalam meningkatkan mutu dan kopetensi yang ada di SMK tersebut menjadi lebih baik, seperti sarana dan prasarana, tenaga pengajar dan perbaikan kurikulum sehingga sesuai dengn kopetensi yang diharapkan. (2)Sekolah SMK di kota Pontianak dapat memberikan informasi secara langsung tentang dunia SMK di tingkat SMP dengan jelas dan efisien. Sekolah 
SMK agar lebih kreatif dalam melakukan sosialiasi tentang Dunia SMK, dengan dapat mendatangi langsung sekolah- sekolah SMP guna memberikan arahan tentang jurusanjurusan yang ada di dalam SMK itu sendiri beserta keunggulannya. Sehingga siswa SMP lebih mudah memahami dalam melanjutkan pendidikannya. (3). Sekolah SMK dan pemerintah diharapkan dapat mensosialisasikan sekolah SMK, jurusan yang ada didalamnya dan informasi lulusan yang dapat diserap oleh industri dengan baik, dapat berwirausaha mandiri, maupun melanjutkan studi ke jenjang yang lebih tinggi sehingga orang tua dan siswa SMP mengetahui prospek lulusan SMK. (4). Sekolah SMP di Kota Pontianak hendaknya memberikan berbagai informasi secara jelas kepada siswa SMP tentang dunia SMK yang seutuhnya, sehingga dapat memberikan arahan kepada siswa untuk memilih sekolah sesuai dengan bakat siswa dalam mencapai cita-cita yang diinginkan. (5). Pihak orang tua dan lingkungan tempat tinggal bisa memberikan informasi, bimbingan dan arahan kepada para siswa SMP berkaitan dengan potensi diri yang mereka miliki sehingga dalam pemilihan sekolah lanjutan sesuai dengan minat,bakat dan kemampuan diri.

\section{DAFTAR PUSTAKA}

Clarke, L. \& Winch, C. (2007). Vocational education. international approaches,

developments and systems. Routledge. 270. Madison Avenue, New York,

Djaali. (2008). Psikologi Pendidikan. PT. Bumi Aksara, Jakarta.
Gumbiner, J. (2003). Adolescent assessment. New Jersey: John Wiley \& Sons.

Ahmad Sobur. (2003). Psikologi umum. Bandung: PT.Tarsito.

Baharudin \& Wahyuni, E, N. (2009). Teori Belajar dan Pembelajaran. Yogyakarta: Ar-ruzz Media

Manggal , K, S.(2007). Essentials Of Education Psychology. New Delhi :PrentileHall.

Pavlova, M. (2009). Tecnology and Vocational Education For SustainableDevelopment. Austalia:Spinger.

Purwanto, H. (1999). Pengantar prilaku manusia untuk keperawatan. Jakarta: Penerbitan Buku Kedokteran EGC.

Sudji Munadi.(2006). Konstrak alat ungkap orientasi pilihan bidang keahlian siswa SMP dan faktor-faktor yang mempengaruhinya. Disertasi doctor, tidak diterbitkan, Universitas Negeri Yogyakarta, Yogyakarta.

Mishra, S., \& Bamba, V. (2012). Impact of family environment on camdemic achievement of secondary school student in science subject. International Journal Of Research In Economic \& Social Sciences, 2, 42- 49.

London, H. H. (1973). Principles and techniques. Columbus, Ohio: Charles E. 